\title{
PROBLEMATIKA DAKWAH DI INDONESIA
}

\author{
Oleh:Meisil B. Wulur ${ }^{1}$
}

\begin{abstract}
ABSTRAK
Tulisan ini bertujuan untuk mendeskripsikan tentang problematika dakwah di Indonesia . Metodelogi yang digunakan adalah Library Research. Pengumpulan data yang digunakan berkaitan dengan problematika dakwah, kemudian tentang upayaupaya dalam mengatasi problema dakwah di Indonseia. Dan data di ambil dari beberapa buku yang berkaitan dengan tulisan ini. Hasil dari pembahasan tulisan ini adalah tentang gambaran problematika dakwah di Indonesia dan upaya-upaya dalam mengatasinya. Tulisan merupakan gambaran dan problematika dakwah, sehingga lebih mudah memahami tantangan dakwah dan lebih memahami apa yangt erjadi dalam kondisi lapangan secara nyata.
\end{abstract}

Kata Kunci: Problematika, Dakwah

\section{A. PENDAHULUAN}

Problematika dakwah sudah menjadi menu sehari-hari bagi pendakwah. Tidak dapat dipungkiri, penyebaran agama islam pada zaman sekarang adalah pewujudan dari dakwah orang-orang alim sebelum kita. Dakwah memerlukan kekuatan ekstra, tidak hanya mengajak dan berbicara saja tetapi lebih dari itu. Mengontrol atau mengevaluasi hasil dakwah adalah suatu masalah yang sangat penting dan urgen dari tujuan dakwah itu sendiri.

Dapat diprediksi bahwa missi dan tantangan dakwah tidaklah pernah akan semakin ringan, melainkan akan semakin berat dan hebat bahkan semakin kompleks.

\footnotetext{
${ }^{1}$ Dosen Tetap IAIM Sinjai
} 
Inilah problematika dakwah kita masa kini. Oleh sebab itu semuanya harus dimenej kembali dengan manajemen dakwah yang profesional dan dihendel oleh tenagatenaga berdedikasi tinggi, mau berkorban dan ikhlas beramal.

Mengamati banyaknya problematika umat dewasa ini, menuntut kehadiran dakwah lebih luas. Tetapi seberapa intensifkah kita sebagai para pendakwah berbicara tentang realitas sosial, tantangan abad informasi, ancaman kultural dan berbagai problema ekonomi yang menghadapi umat. Persoalan ini menjadi sangat penting dan mendesak untuk diperhatikan, karena dalam abad informasi ini berbagai model kultural dan gaya hidup yang tidak selalu sesuai bahkan bertentangan, bisa dengan mudah mendikte kesadaran umat Islam, melalui berbagai media, terutama TV.

Di mana ada empat kelompok dalam masyarakat, yakni orang tua, dewasa, pemuda dan anak-anak. Dakwah Islam harus mampu mentarbiyahkan keempat kelompok masyarakat tersebut, dengan stressing pembinaan generasi muda dan anakanak sebagai penentu peradaban masa mendatang. Oleh karenanya, aktivitas dakwah yang kita lakukan sebaiknya tertata secara utuh, di dalamnya harus memilik sistem yang komprehensif.

Disis lain, intelektual atau cendikiawan kurang menampakan pemahaman persoalan masyarakat lapisan bawah akibat kecenderungan elitis dan jauhnya hubungan secendekiawan dengan seluruh lapisan masyarakat, terutama masyarakat 
lapisan bawah. Inilah yang belum terselesaikan dalam persoalan demokratisasi dakwah, seakan aktifitas dakwah itu tidak memiliki kolerasi dengan politik.

\section{B. PEMBAHASAN}

\section{Problematlika Dalam Dakwah di Indonesia}

Risiko dakwah tentu adalah sunntatullah atau wajar terjadi. Karena, yang kita dakwahkan ajaran Islam. Sementara obyek dakwah kita yang di rumah, sekolah, kampus, atau tempat kerja hampir semuanya telah diselimuti aturan sekuler atau pemikiran yang 'sesat'yang jelas-jelas bertentangan dengan Islam. Otomatis dakwah kita tidak akan berjalan semulus di jalan tol. Banyak tantangan dakwah yang di hadapi dengan berbagai masalah yang kompleks.

\section{a. Problematika Dakwah Kontemporer}

Secara keseluruhan beberapa isu yang terkait dengan problematika kehidupan umat islam yang terbagi dalam beberapa bagian pokok. ${ }^{2}$ Pertama, Radikalisme dan ekstrimisme Islam. Kedua, Runtuhnya kerukunan Internal umat beragama. Ketiga, Merebaknya aliran Islam Sempalan

Persoalan yang kita hadapi sekarang adalah tantangan dakwah yang semakin hebat, baik yang bersifat internal maupun eksternal ${ }^{3}$. Tantangan itu muncul dalam berbagai bentuk kegiatan masyarakat modern, seperti perilaku dalam mendapatkan hiburan (entertainment), kepariwisataan dan seni dalam arti luas, yang semakin membuka peluang munculnya kerawanan-kerawanan moral dan etika.

\footnotetext{
${ }^{2}$ Ibnu Qomar El-Banthory, Peta Dakwah, h. 31

3 Problem-problem dakwah internal, yakni problem-problem, permasalahan-permasalahan, dan hambatan-hambatan dakwah yang bersumber dan berasal dari lingkup internal kaum muslimin sendiri. Dan kedua, problem-problem dakwah eksternal, yakni problem-problem, hambatanhambatan, dan tantangan-tantangan dakwah yang bersumber dan berasal dari berbagai kalangan dan pihak ummat manusia di luar lingkup kaum muslimin.
} 
Problem-problem di jalan perjuangan dakwah, mencakup dan meliputi dua macam problem, sebagai berikut $:^{4}$

\section{1) Problem Dakwah Internal}

Problem-problem internal tentu juga sangat banyak, beragam dan bertingkattingkat, yang bisa kita klasifikasikan ke dalam lima kelompok dan kategori. Pertama, problem-problem, permasalahan-permasalahan, dan hambatan-hambatan dakwah internal yang bersumber dan berasal dari kondisi internal diri setiap dai sendiri. Kedua, yang bersumber dan berasal dari kondisi internal setiap kelompok, golongan, organisasi, jamaah, dan pergerakan dakwah yang ada di tubuh kaum muslimin. Ketiga, yang bersumber dan berasal dari kondisi internal kalangan para dai dan kelompok dakwah secara umum. Keempat, yang bersumber dan berasal dari kondisi internal ummat Islam dalam lingkup Ahlus-Sunnah wal-Jama'ah. Dan kelima, yang bersumber dan berasal dari kondisi internal kaum muslimin secara keseluruhan.

Disamping itu, dan bahkan sebelum itu, arahan Al-Qur'an sendiri sangat menekankan hal itu. Perhatikanlah, misalnya, firman-firman Allah (yang artinya) berikut ini: ${ }^{5}$

Dan mengapa ketika kamu ditimpa musibah (pada peperangan Uhud), padahal kamu telah menimpakan kekalahan dua kali lipat (kepada musuhmusuhmu pada peperangan Badar), kamu berkata: "Darimana datangnya (kekalahan) ini?" Katakanlah: "Itu dari (kesalahan) dirimu sendiri". Sesungguhnya Allah Maha Kuasa atas segala sesuatu. (QS. Ali 'Imraan: $165)$.

Apa saja kebaikan yang kamu peroleh adalah dari Allah, dan apa saja keburukan yang menimpamu, maka itu adalah dari (kesalahan) dirimu sendiri.

${ }^{4}$ Ahmad Mudzofar Jufri, Problem Dakwah: Internal Sebelum Eksternal ;http://Www. Facebook. Com/Ustadz Ahmad Mudzoffar Jufri (أبو عامر). Di akses pada tanggal 30 Mei 2013

${ }^{5}$ Terjemahan Al-Quran Departemen Agama RI 
Kami mengutusmu menjadi rasul kepada segenap manusia. dan cukuplah Allah menjadi saksi" (QS. An-Nisaa' [4]: 79).

Dan apa saja musibah yang menimpa kamu maka adalah disebabkan oleh perbuatan tanganmu sendiri, dan Allah memaafkan sebagian besar dari kesalahan-kesalahanmu (QS.Asy-Syuuraa:30)

\section{2) Problem Dakwah Eksternal}

Karena penyelesaian problem internal itu sendiri sebenarnya merupakan bagian langkah terpenting dari penanganan dan penyelesaian problem eksternal. Problem-problem, hambatan-hambatan dan tantangan-tantangan dakwah yang bersifat eksternal, tentu saja banyak dan beragam sekali. Namun secara umum bisa kita ilustrasikan dan ringkaskan dalam empat poin di bawah ini:

- Berupa makar yang terus-menerus dan bertubi-tubi dari musuh-musuh Islam dan kaum muslimin (lihat: QS.Al-Anfaal [8]: 30; QS. Ar-Ra'd [13]: 42; QS. Ibrahim [14]: 46; QS. Saba' [34]: 33; QS. Ath-Thaariq [86]: 1517; Dan lain-lain).

- Kerja sama mereka dalam membuat dan melaksanakan konspirasi terhadap Islam, dakwah Islam dan Ummat Islam (QS. Al-Anfaal [8]: 73; QS. An-Naml [27]: 48-53).

- Keragaman cara dan strategi mereka dalam upaya-upaya menghambat, menghadang dan menghentikan setiap perjalanan serta laju dakwah Islam, dari kelompok, organisasi, pergerakan dan jamaah manapun.

- Kekuatan, kecanggihan dan kemodernan sarana serta prasarana yang mereka pakai dan gunakan dalam membuat dan melaksanakan makar atau konspirasi mereka terhadap Islam, dakwahnya, pergerakannya dan kaum muslimin. 


\section{b. Aktivitas Dakwah dalam Moderenitas Masyarakat}

Moderenitas berasal dari kata modern, yaitu segala sesuatu yang berkaitan dengan kehidupan masa kini. Dari segi istilah moderitas adalah pandangan dan sikap hidup yang bersangkutan dengan kehidupan masa kini, yang banyak dipengaruhi oleh peradaban modern. ${ }^{6}$

Peradaban Barat mempunyai dampak sangat besar terhadap moderenitas. Yang telah merambah dalam kelangsungan hidup manusia. Yang hampir disemua sector; perekonomian, tekhnologi, pendidikan. Namun sisi lain, moderenitas juga telah melahirkan berbagai masalah atau problematika yang kompleks dalam kehidupan manusia. Artinya ada nilai plus-mines dengan adanya moderenisasi di Indonesia yang berhubungan dengan Iptek dan Imtaq pada diri atau kepribadian seseorang dalam menyaring sesuatu hal yang dihadapi seseorang.

Arus moderenisasi masuk dalam wilayah dakwah sekaligus menjadi problem dakwah bagi para aktivis dakwah. Ketika masyarakat perkotaan tak lagi memiliki waktu untuk pergi ke majelis ta'lim. Namun kebutuhan mereka dalam era tekhnologi dan informasi sangat tergantung dalam pelayanan berbasis tekhnologi. Dan sikap hedonisme masyarakat, maka dakwah tak lagi bisa dilakukan dengan sekedar ceramah dan tabliq Akbar di mesjid-mesjid, namun dakwah harus dijalankan sesuai dengan kebutuhan masyarakat yang sejalan dengan logika masyarakat industry atau masyarakat modern.

\section{3) Kegelisahan dan Keterasingan Jiwa Masyarakat Moderen}

Kerawanan moral dan etik itu muncul semakin transparan dalam bentuk kemaksiatan karena disokong oleh kemajuan alat-alat teknologi informasi mutakhir seperti siaran televisi, keping-keping VCD, jaringan Internet, dan sebagainya.

6 Ibnu Qomar El-Banthory,Dkk, Peta Dakwah Di Indonesia, Edisi Pertama. Pamulang;Formadia Press, 2010), h. 25 
Maka dakwah Islam sebenarnya bukan lagi masalah halal dan haram, sebab kriteria sekarang menuntut perangkat penelitian yang bergantung pada Iptek yang disebut diatas. Halal-haram tidak nampak lagi dengan mata telanjang dengan masuknya arus globalisasi. Dan disini penulis berpendapat bahwa lahan dakwah yang perlu digarap adalah sentuhan psikologi terhadap masyarakat. Hal ini dikarenakan mereka mengalami kegelisahan dan kegersangan jiwa dalam beragama. Yang menimbulkan penyakit Fisik dan Psikis yang tentunya perlu penangan yang serius secara klinis.

Tidak dipungkiri mereka mengharapkan siraman keagamaan yang memberi terapi pada kedalaman jiwanya yang telah dihilangkan dan dikaburkanoleh hasil-hasil kemoderenan yang tidak termenej dengan baik dalam kehidupannya. Sehingga mereka kehilangan “makna hidup”.

Dakwah dalam moderenitas memiliki beberapa catatan kelemahan, sebagai berikut : ${ }^{7}$

- Muatan dakwah yang tidak up to date.

- Kemasan yang kurang menarik

- Metode dakwah dan media yang masih lemah

Dengan dua sisi moderenitas yaitu plus-minesnya yang merupakan problem dakwah yang cukup serius. Maka langkah yang harus diambil dari positifnya adalah para pendakwah harus mampu melihat sebagai sebuah peluang dalam mengembangkan Islam. Serta sisi negatifnya para pendakwah harus mampu mengambil langkah agar moderenitas tidak menjadi dampak kerusakkan yang luas dalam beragama.

\footnotetext{
${ }^{7}$ Ibnu Qomar El-Banthory,Ibid, h. 46
} 


\section{4) Aspek Spiritual Melalui Pola Kepribadian Dalam Arus Dakwah Moderenisasi}

Dalam arus moderenisasi banyak yang dikesampingkan oleh para pakar Barat dalam mengetahui kepribadian seseorang, yang dilihat melalui sisi psikologis dalam aspek Spritual Islam. Hal ini bisa dimengerti, karena mereka tidak tahu bagaimana cara mengkajinya dengan penelitian yang objektif. ${ }^{8}$

Keterkaitan hal ini Dr. Usman Najati bisa memahami kalau ahli-ahli jiwa modern maupun klasik mengesampingkan aspek spiritual dalam kajian mereka. Padahal itu sangat penting. Dan aspek-aspek tersebut menurut Dr. Usman Najati yang menyerukan aspek spiritual sebagai acuan kajian spiritual, berdasarkan konsep Alquran, dengan acuan analisisnya sebagai berikut: ${ }^{9}$

- Pola kepribadian orang beriman ${ }^{10}$

\footnotetext{
${ }^{8}$ Totok Jumantoro, Psikologi Dakwah; Dengan Aspek-Aspek Kejiwaan Yang Qurani, (Edisi Pertama, Jakarta; Amzah, 2001), h. 142

${ }_{9}^{9}$ Totok Jumantoro, Psikologi Dakwah; Dengan Aspek-Aspek Kejiwaan Yang Qurani ,h. 143

${ }^{10}$ Totok Jumantoro, ibid, h.143-144. Yang tergambar dalam Alquran, antara lain:

a. Muslimin :

- $\quad$ Beriman kepada Allah dan Rasul-Nya, (QS. 4;136)

- Masuknya islam secara keseluruhan, (QS. 2;208-209)

- Dilarang mengingkari Allah, (QS. 7; 158)

- $\quad$ Syahadat, (QS. 7;158)

b. Mukminin:

- Mengamalkan ajaran Islam,

- Menyeru yang ma'ruf dan mencegah yang munkar,( QS. 9;71)

- Gemetar jika disebut agama Allah, (QS. 8;2-4)

- Menepati janji dan memelihara amanah, (Qs. 32;15-16)

- Shalat dengan khusyu, (QS. 16;94-97)

- $\quad$ Berjihad dijalan Allah, (QS. 49; 14-15)

c. Muttaqin :

- $\quad$ Berpuasa, (QS. 2;183)

- $\quad$ Makan minum yang halal, (QS. 5;88)

- Berakaian taqwa, (QS.7;26)

- $\quad$ Sillaturahmi, (QS.4;1)

- $\quad$ Mendirikan mesjid, (QS. 9;107-110)

- Qiyamul lail, (QS. 17;79-80)
} 
- Pola kepribadian orang kafir ${ }^{11}$

- Pola kepribadian orang Munafik ${ }^{12}$

Pola gerakan dakwah yang ada sampai saat ini rupanya tidak memperhatikan titik keseimbangan dan proposi terhadap nafs-nafs yang ada pada manusia, sehingga pertumbuhan nafs tidak seimbang, yang akibatnya adalah $:^{13}$

- Dakwah tidak dimulai pada titik yang benar dan tepat, yaitu dakwah nafsiah. Akibatnya menghasilkan generasi yang memahami islam secara konseptual dan teori ilmu, sepertinya dengan ilmu-ilmu yang lain. Maka akan timbul kegagalan banyak melahirkan sarjana Islam, tetapi hanya

${ }^{11}$ Totok Jumantoro, Ibid, h. 144. Kepribadian orang kafir, dalam Alqur'an:

a. Kelompok fasiqin

- $\quad$ Menyembunyikan kebenaran, (Qs. 61;5), dst

- $\quad$ Tidak mau mengamalkan kebenaran, (Qs. 5;47-50)

- Menukar/menjual hukum Allah, (Qs. 3;187-188)

b. Kelompok orang Murtad

- $\quad$ Sia-sia amal orang yang murtad, (Qs. 2;217),dst

- $\quad$ Terhapus amal mereka, (Qs. 5;5),dst

c. Kafir

- $\quad$ Mukanya hitam pada hari kiamat, (Qs. 47;25-32),dst

- Amalan orang kafir taqlid buta, (QS. 41;41-43),dst

- $\quad$ Tidak ada gunanya diberi peringatan, karena hari mereka buta, (QS. 26;2-6),dst

- Amalan mereka sia-sia, (QS. 8;36-37), dst

${ }^{12}$ Totok Jumantoro. Ibid, h. 145. Kepribadian orang munafik, dalam Alquran:

a. Sifat orang Munafik

- $\quad$ Tidak berpendirian, (QS. 4;142, QS. 57;14)

- $\quad$ Tidak dapat dipercaya, (QS. 9;75-79)

- $\quad$ Bohong dan dusta, (QS. 2;8-10)

- Janjinya tidak ditepati, (Qs. 4;60-63)

- Ibadahya riya, (QS. 8;49)

- $\quad$ Enggan berjihad, (QS. 9;86-87)

b. Tamsil bagi orang munafik

- $\quad$ Laksanakan menyalakan lampu tapi tidak menerangi, (Qs. 2;17)

- $\quad$ Seperti orangtuli dan buta, (QS. 2;18-20)

- $\quad$ Seperti kayu besar yang bersandar, (QS. 63;4)

- $\quad$ Sekalipun menarik mereka tetap bodoh dan tidak bebobot, (Qs. 2;11-13)

${ }^{13}$ Isep Zainal Arifin, Bimbingan Penyuluhan Islam; Pengembangan Dakwah Melalui Psikoterapi Islam, (Cet. I; Gravindo Persada; Jakarta, 2009). h, 186-188 
memahaminya sebagai konsep dan teori belaka, tetapi tidak memancarkan pribadi seorang muslim.

- Terdapat kecerendungan dakwah hanya mengajak orang lain, tetapi lupa mengajak, mengasah, diri sendiri. Akibatnya banyak para da'I hanya bisa memukau umat tetapi sesungguhnya gagal pada diri sendiri.

- Umat berhasil digerakkan dan disentuh jiwa Mutmainnahnya tetapi lupa diasah jiwa sawiyahnya. Yang merupakan potensi kecerdasan yang menunya adalah ilmu dan informasi. Akibatnya mudah diajak menangis namun penguasaan keislamanya kurang, yang akhirnya lahir generasi yang semangat namun gagap.

- Tayangan dan tontonan yang merangsang syahwat dan glamournya dunia, bahkan bacaan dan makanan serta minuman yang membangkitkan libido. Ternyata mampu membangkitkan potensi ammarah dan lawwamah. Tanpa diimbangi nafsu mutmainnah dan sawwiyah. Akibatnya tampillah masyarakat yang tidak tabu terhadap seksualitas, narkoba, dan generasi yang hedonis. Yang bersamaan lahir pula generasi Islam yang radikal, emosional, dan mudah dihasut.

- Generasi yang hanya didasari nafs lawwamah dan sawwiyahnya saja, akibatnya menghasilkan pendakwah yang ingin ketenaran, dan ingin terlihat gebyar.

- Kegagalan dakwah nafsiyah menghasilkan generasi yang buta terhadap kahikat diri sendiri dan hakikat hidup sebenarnya.

Klasifikasi diatas berdasarkan pada akidah, yang identik dengan tujuan-tujuan dakwah sebagai petunjuk dalam menghadapi problematika dakwah. Dan dengan petunjuk diatas maka ini merupakan langkah untuk menyesuaikan strategi dakwah dilapangan. Dan apa yang akan dilakukan oleh para aktivis dakwah. Dan penelitian diatas dengan merujuk pada Alqur'an merupakan kajian yang perlu diapresiasikan melalui aplikasi dan implementasi terhadap kajian tersebut. 


\section{5) Fenomena Da’i dan Isu-isu Sosial Kemasyarakatan}

a) Fenomena da'i yang sebagai catatan yang menjadi penghambat dakwah, diantaranya adalah:

- Adanya kesenjangan antara da'i dan mad'u

Tidak adanya komunikasi yang sejajar antara keduanya. Masyarakat terasa sungkan untuk mengadu masalah yang dihadapinya, sementara da'i tidak tahu apa yang menjadi kebutuhan masyarakat. Dan nampaknya para da'i menjadi pihak yang terlayani, dan masyarakat menjadi pihak yang melayani.

- Krisis Keteladanan

Sebelum mengajak sebaiknya seorang da'i lebih dulu melakukannya. Dan sekarang ini kita mengalami krisis figur seorang da'i. Karena sebagian para da'i tidak konsisten dengan apa yang diucapakan dan apa yang dilakukannya. Sehingga terkadang umat bingung dengan sikap da'i tersebut.

- Lemahnya Strategi dakwah

Strategi dakwah yang dijalankan para da'i terasa hampa dan mendatar. Hal ini nampak bahwa kegiatan dakwah dianggap hanya sebatas ceramah di mimbar, atau tabliq. Namun banyak bentuk-bentuk kegiatan dakwah yang memilki varian-varian yang cocok untuk digunakan. Baik lewat media, atapun bisnis, dan sosial budaya.dll.

b) Isu-isu Sosial Kemasyarakatan

- Kemiskinan

- Penyalahgunaan narkotika

- Ekploitasi anak

- Korupsi dan kolusi

- Global warning

- Fenomena bunuh diri

- Pelecehan seksual orang-orang terdekat 


\section{Upaya-Upaya Dalam Mengatasi Problematika Dakwah di Indonesia}

\section{a. Upaya Mengatasi Problematika Internal}

Upaya tersebut secara umum meliputi minimal tiga langkah:

- Dengan menyadari, mengakui, mengenali dan memahami setiap problem internal dengan benar, tepat dan proporsional.

- Mengklasifikasikannya sesuai dengan kategori dan peringkat serta tingkat prioritasnya.

- Mencarikan solusi, penanganan dan penyelesaian dengan mendahulukan dan mengutamakan yang lebih penting dan urgen berdasarkan urutan tingkat prioritasnya.

\section{b. Upaya untuk Menghadapi Problem Eksternal}

Upaya tersebut, Al-Qur'an memberikan dua kata kunci utama, yaitu: taqwa dan sabar. Meskipun di tataran aplikasi dan implementasinya, tentu saja dibutuhkan penjabaran yang panjang. Perhatikan misalnya firman-firman Allah (yang artinya) berikut ini: ${ }^{14}$

Dan jika kamu bersabar dan bertakwa, niscaya tipu daya mereka tidak akan mendatangkan kemadharatan sedikitpun kepadamu. Sesungguhnya Allah mengetahui segala apa yang mereka kerjakan. (QS. Ali 'Imraan: 120).

Kamu sungguh-sungguh akan diuji terhadap hartamu dan dirimu. Dan (juga) kamu sungguh-sungguh akan mendengar dari orang-orang yang diberi Kitab (Ahli Kitab) sebelum kamu dan dari orang-orang yang mempersekutukan Allah, gangguan yang banyak yang menyakitkan hati. Dan jika kamu bersabar dan bertakwa, maka sesungguhnya yang demikian itu termasuk urusan yang patut diutamakan. (QS. Ali 'Imraan [3]: 186).

${ }^{14}$ Ahmad Mudzofar Jufri, Problem Dakwah: Internal Sebelum Eksternal ;http://Www. Facebook. Com/Ustadz Ahmad Mudzoffar Jufri (أبو عامر). Di akses pada tanggal 30 Mei 2013 


\section{c. Upaya menghindari Konflik Dakwah yang terjadi dalam tubuh umat Islam}

Ada beberapa rancangan kerja dakwah yang dapat dilakukan dalam menjawab problematika umat dewasa ini.yaitu: ${ }^{15}$

- Memfokuskan aktivitas dakwah untuk mengentaskan kemiskinan umat

- Menyiapkan elit strategis Muslim untuk disuplai keberbagai jalur kepemimpinan bangsa sesuai dengan bidang keahliannya masing-masing

- Membuat peta social umat sebagai informasi awal bagi pengembangan dakwah

- Mengintegrasikan wawasan etika, estetika, logika, dan budaya dalam berbagai perencanaan dakwah

- Mendirikan pusat-pusat studi informasi umat secar professional dan berorientasi pada kemajuan IPTEK

- Menjadikan mesjid sebagai pusat kegiatan: ekonomi. Kesehatan, dan kebudayaan umat Islam.

- Menjadikan Islam sebagai pelopor yang profetis, humanis, dan transformative.

Dengan melihat dinamika sosial yang terus bergulir ke arah moderen, dengan memiliki dampak yang besar dalam perubahan masyarakat. Maka dakwah harus mengambil peran yang strategis untuk menghindari dampak negatif tersebut. Ada lima langkah optimalisasi peran dakwah, sebagai berikut ${ }^{16}$

- Penguatan materi dakwah dengan memasukkan materi sosial kemasyarakatan, seperti: korupsi, kemiskinan, dan penindasan, serta isuisu sosial yang merupakan realitas hidup.

- Melakukan perubahan pada aspek metodelogi dakwah, terutama dalam bentuk monolog ke entuk dialog.

\footnotetext{
${ }^{15}$ Usman Jasad, Dakwah Dan Komunikasi Transformasi; Mencari Titik Temu Dakwah Dan :Realitas Umat, (Cet.I; Makasar; Alaudin Makassar, 2011),h. 73

${ }^{16}$ Ibnu Qomar El-Banthory,Dkk, lo.cit h.39-43
} 
- Menjalin kemitraan dengan instituti lain dalam pembinaan yangdilakukan secara bersama-sama.

- Memperkuat keperpihakan pada kaum tertindas.

- Memberikan advokasi kepadamasyarakat terhadap kasus yang dihadapinya

\section{d. Upaya Pembaruan Dakwah dengan Konsep Psikologis dengan Keragaman sosial}

Dengan adanya deviasi moral secara massal dan distorsi nilai kemanusiaan secara umum. Yang perlu dilakukan adalah: ${ }^{17}$

- Upaya para pendakwah harus lebih memunculkan teori Psikolog Islam dari Alqur'an dan Sunnah.

- Adanya kesadaran bahwa dalam masyarakat, bahwa selalu ada jurang pemisah yang lebar antara moderenisasi dan tradisi yang perlu dijembatani dan disikapi secara bijak.

- Kesadaran pengelola lembaga-lembaga, yang memakai simbolisasi Islam, seperti media cetak maupun elektronik, ormas-ormas islam. Terutama yang bergerak dalam kanca informasi untuk mengkedepankan tanggung jawab dan masalah hati hurani.

\section{e. Upaya melakukan Srategi Alternatif}

Ada lima macam sikap dan strategi umum yang telah diupayakan untuk ini $:^{18}$

- Sikap adoptif yang mengambil semua prodak barat melaui filter dengan maksud mengejar ketinggalan.

${ }^{17}$ Ahmad Anas, Paradigm Dakwah Kontemporer, (Cet.I, Semarang; Pustaka Rezki Putra, 2002), h. 195-197

${ }^{18}$ Ahmad Anas, ibid, 212-213 
- Strategi isolatif, yang menganggap Islam sebagai alternatif dasar peradaban. Sebagai konsekuensinya memutuskan hubungan kultur denga Barat, kecuali Sains dan tehnologi.

- Strategi seletif, dengan cara menyeleksi acara-acara TV dan Radio.

- Strategi Alternatif melalui penyiaran (prodaction house sendiri) yang berani bersaing dengan jaringan televisi Sekuler.strategi integratif, dengan membentuk sekolah-sekolah alternatif komplementer yang memanfaatkan Audio Visual dengan tayangan Islami.

\section{f. Upaya Mengadopsi kebiasaan Intelektual Masyarakat Islam pada masa Nabi.}

Empat kesadaran yang pada masa nabi cukup dijunjung tinggi, dan sekarang harus dibangkitkan lagi pada masyarakat indonesia yang mayoritas Islam: ${ }^{19}$

1) Watak kosmopolitan umat Islam. Dengan adanya watak ini maka orangorang muslimlah yang pertama kali menginternasionalisasikan ilmu pengetahuan. Yang menjadi milik indonesia.

2) Sifat terbuka terhada ide-ide luar. Pada abad ke-8 hingga ke-15 mereka mampu mengharmonisasikan prinsip peradaban yang diakomodasikan dari filsafat Yunani, Hindu, dan Persia.

3) Sikap egaliter, dalam mempelajari dan mewarisi ilmu. Islam tidak menegnal diskriminasi berdasarkan strata sosial. Segalailmu bisa diambil asalkan tidak bertentangan dengan prinsip urgen dari akidah Islam

4) Pola keseimbangan antar dimensi keduniaan dan keakhiratan, yang dikenal dengan konsepiman dan amal sholeh.

\footnotetext{
${ }^{19}$ Ahmad Anas, Ibid, 224-225
} 


\section{PENTUP}

\section{Kesimpulan}

Mengamati banyaknya problematika umat dewasa ini, menuntut kehadiran dakwah lebih luas. Tetapi seberapa intensifkah kita sebagai para pendakwah berbicara tentang realitas sosial, tantangan abad Informasi, ancaman kultural dan berbagai problema ekonomi yang menghadap umat. Persoalan ini menjadi sangat penting dan mendesak untuk diperhatikan, karena dalam abad informasi ini berbagai model kultural dan gaya hidup yang tidak selalu sesuai bahkan bertentangan, bisa dengan mudah mendikte kesadaran umat Islam, melalui berbagai media. Jika pola ini yang dipilih, ada beberapa hal yang harus dipertimbangkan, minimal sebagai berikut:

- Pendalaman keilmuan islam harus lebih ditingkatkan

- Pemberian materi baru lebih selektif

- Jumlah kuantitas tidak menjadi ukuran pendanaan

- Dakwah, bukan sekedar ajakan kejalan yang lurus

- Targetnya jelas dan konkrit

- Hasil yang jelas

\section{Saran}

Perlunya Pengkajian sumber asli Islam dengan menguasai ilmu alat, berupa bahasa dan alat bantu metodologi ijtihad dan ilmiah. Dan Pengembangan semangat kemanusiaan dengan penelitian mengenai kecenderungan masyarakat. Dan diperlukan Kaderisasi serta peningkatan kualitas ekonomi para mubaligh yang meliputi Peningkatan kualitas wawasan. 


\section{DAFTAR PUSTAKA}

Ahmad Anas, Paradigm Dakwah Kontemporer, Cet.I, Semarang; Pustaka Rezki Putra, 2002

Ahmad Mudzofar Jufri, Problem Dakwah: Internal Sebelum Eksternal ;http://Www. Facebook. Com/Ustadz Ahmad Mudzoffar Jufri (أبو عامر). Di akses pada tanggal 30 Mei 2013

Acep Aripuddin, Penegembangan Metode Dakwah; Respon Dai Terhadap Dinamika Kehidupan Beragama Dibawah Kaki Ceremai, Cet.I, Jakarta; Raja Gravindo, 2011

H.M. Tata Taufik, Etika Komunikasi; Komparasi Komunikasi Islam Dan Barat, Cet. I, Bandung; Pustaka Setia, 2012

Ibnu Qomar El-Banthory,Dkk, Peta Dakwah Di Indonesia, Edisi Pertama. Pamulang;Formadia Press, 2010

Isep Zainal Arifin, Bimbingan Penyuluhan Islam; Pengembangan Dakwah Melalui Psikoterapi Islam, (Cet. I; Gravindo Persada; Jakarta, 2009).

Jalaluddin Rahmat, Psikologi Komunikasi, Cet.Duapuluhtiga, Bandung; Remaja Rosda Karya, 2005

Muhammad Tholhah Hasan, Ahlusunnah Waljamaah; Dalam Presepsi Dan Tradisi NU, Cet.III, Jakarta; Lantabora Press, 2005

Totok Jumantoro, Psikologi Dakwah; Dengan Aspek-Aspek Kejiwaan Yang Qurani, Edisi Pertama, Jakarta; Amzah, 2001

Tigor Pangaribuan, Kamus Popular Lengkap, Edisi Kedua, Bandung; Pustaaka Setia, 1997

Usman Jasad, Dakwah Dan Komunikasi Transformasi; Mencari Titik Temu Dakwah Dan :Realitas Umat, Edisi Pertama. Makasar: Alaudin Makassar, 2011 